\title{
PARTISIPASI PRIA DALAM PENGGUNAAN VASEKTOMI DI KECAMATAN MARO SEBO KABUPATEN MUARO JAMBI
}

\author{
Male Participation In Using Vasectomy In Maro Sebo District, Muaro Jambi Regency
}

\author{
Guspianto ${ }^{1}$ \\ ${ }^{1}$ Fakultas Kesehatan Masyarakat Universitas Jambi
}

\begin{abstract}
Abstrak
Prevalensi pemakaian kontrasepsi masih memiliki masalah terkait disparitas kesetaraan gender yaitu masih rendahnya partisipasi pria dalam menggunakan kontrasepsi khususnya metode vasektomi. Penelitian ini menggunakan desain kualitatif yang bertujuan untuk menganalisis partisipasi pria dalam penggunaan vasektomi dalam hubungannya dengan faktor pengetahuan, promosi dan informasi, akses pelayanan, dan sosial budaya di Kecamatan Maro Sebo Kabupaten Muaro Jambi. Hasil penelitian ini menemukan partisipasi pria dalam penggunaan vasektomi masih rendah yang berkemungkinan dipengaruhi oleh rendahnya pengetahuan tentang vasektomi, terbatasnya akses promosi dan informasi KB pria, terbatasnya akses pelayanan vasektomi, dan adanya nilai-nilai sosial budaya yang kurang mendukung. Direkomendasikan untuk meningkatkan upaya sosialisasi dan konseling secara intensif dan kontinyu dengan sasaran pria (suami), pendekatan dan koordinasi dengan tokoh masyarakat dan agama guna mendukung program KB khususnya penggunaan vasektomi.
\end{abstract}

Kata kunci : Keluarga Berencana, Partisipasi pria, Vasektomi.

\begin{abstract}
The prevalence of contraceptive use still has problems related to gender equality disparities such as low male participation in using contraception, especially the vasectomy method. This study using a qualitative design that aimed to analyze the male participation in using vasectomy in relation to knowledge, promotion and information, access to services, and socio-cultural in Maro Sebo District, Muaro Jambi Regency. The results of study found that the male participation in using vasectomy was still likely to be influenced by low knowledge about vasectomy, limited access to promotion and information on family planning, limited access to vasectomy services, and lack of socio-cultural values. It is recommended to increasing dissemination and counseling efforts intensively and continuously for male targets, approaching and coordinating with community and religious leaders to support the family planning programs, especially in using vasectomy.
\end{abstract}

Keywords: Family Planning, Male Participation, Vasectomy.

Korespondensi : Guspianto

Email : guspianto@unja.ac.id

\section{PENDAHULUAN}

Program Keluarga Berencana (KB) telah mengubah struktur kependudukan, tidak hanya dalam arti menurunkan tingkat kelahiran dan laju pertumbuhan penduduk, namun mengubah mindset masyarakat terhadap nilai anak serta kesejahteraan dan ketahanan keluarga. Program KB membantu memperbaiki kualitas hidup dan kesehatan reproduksi melalui kesadaran individu dan pasangannya ${ }^{1}$. Kesuksesan besar program KB ditandai dengan keberhasilan Indonesia menurunkan angka Total Fertility Rate (TFR) secara dramatis dari 5 menjadi 2.3 dan menaikkan angka CPR dari 5\% menjadi di atas 50\% dalam 3 dekade (1960-1990). Namun sejak perubahan situasi politik tahun 1998 diikuti sistem desentralisasi, capaian 
program $\mathrm{KB}$ cenderung stagnan dimana pada periode 2002 hingga 2017, TFR sedikit turun dari 2.6 menjadi 2,4 dan CPR sedikit naik dari $60,3 \%$ menjadi $66 \%{ }^{2}$. Disparitas prevalensi kontrasepsi terkait rendahnya partisipasi pria (suami) berkontrasepsi menjadi masalah tersendiri dalam program $\mathrm{KB}^{3}$.

Angka partisipasi pria ber-KB di Indonesia masih sangat rendah yaitu sebesar $3,8 \%$ (kondom 3,1\% dan vasektomi $0,7 \%$ ), jauh lebih rendah dibandingkan negaranegara lain seperti Filipina (24\%), Banglades $(19,1 \%)$, Malaysia (16,8\%), dan Thailand $(9 \%)^{4}$. Di Provinsi Jambi, angka partisipasi KB pria sebesar 2,5\% (kondom 2,3\% dan vasektomi $0,2 \%$ ) terendah di Kabupaten Muaro Jambi $(1,3 \%)$ terutama di Kecamatan Maro Sebo hanya $(0,25 \%)^{5}$.

Pentingnya peran serta pria pada program KB karena pria terlibat nyata dalam fertilitas yaitu mitra reproduksi dan seksual wanita, sehingga sangat beralasan jika harus berbagi tanggung jawab dan peran yang seimbang. Pria juga bertanggungjawab secara sosial dan ekonomi bagi anak-anaknya sehingga keterlibatannya dalam keputusan reproduksi akan membentuk ikatan lebih kuat dalam keluarga. Peningkatan partisipasi pria dalam program KB adalah langkah tepat untuk meningkatkan kualitas keluarga, mendorong kesetaraan gender, dan mensukseskan tujuan pembangunan ${ }^{6}$.

Partisipasi pria ber-KB adalah wujud perilaku kesehatan untuk meningkatkan kesehatan ibu, bayi dan anak serta menurunkan angka kematian ibu dan bayi. Perilaku kesehatan dipengaruhi tiga faktor yaitu predisposisi (pengetahuan, keyakinan, sikap, nilai, budaya, dan lain-lain); pendukung (keterampilan, sumber daya, keterjangkauan, kebijakan, dan lain-lain); dan pendorong (dukungan sosial, peran petugas, dan lainlain $)^{7}$. Hasil riset telah membuktikan adanya faktor-faktor yang berpengaruh terhadap partisipasi pria dalam pengunaan $\mathrm{KB}$ dan khususnya vasektomi, antara lain faktor sosial dan individu, nilai anak, permintaan $\mathrm{KB}$, faktor persediaan, output layanan (akses, kualitas layanan, image), dan pemanfaatan pelayanan $\mathrm{KB}$, sosialisasi dan promosi, target program, biaya, dukungan isteri, stigma KB pria, kondisi politik, sosial, budaya dan agama, komitmen pemerintah, dan lain-lain ${ }^{8,9}$.

Penelitian ini bertujuan untuk menganalisis partisipasi pria dalam penggunaan kontrasepsi vasektomi dan faktor-faktor yang berhubungan dengan partisipasi pria tersebut meliputi pengetahuan, akses promosi dan informasi, akses pelayanan dan sosial budaya di Kecamatan Maro Sebo Kabupaten Muaro Jambi

\section{METODE}

Metode penelitian yang dilakukan adalah studi kualitatif untuk memahami fenomena partisipasi pria dalam pengunaan vasektomi di Kecamatan Maro Sebo Kabupaten Muaro Jambi. Pengumpulan data melalui wawancara mendalam terhadap 10 (sepuluh) informan yang dipilih secara purposive didasarkan prinsip appropriateness dan adequacy, meliputi: pria akseptor vasektomi, pria akseptor non vasektomi; pria non akseptor, petugas penyuluh lapangan $\mathrm{KB}$, kader KB, tokoh masyarakat, dan tokoh agama. Data yang tersedia diolah dan disajikan dengan tahapan: data reduction, data display dan data conclusion, serta dianalisis menggunakan analisis konten ${ }^{10}$.

\section{HASIL}

\section{Partisipasi KB Pria}

Hasil telaah dokumen menunjukkan partisipasi pria dalam penggunaan vasektomi di Kecamatan Maro Sebo sangat rendah yaitu hanya 3 akseptor $(0,07 \%)$ dari 4.343 PUS. Hasil wawancara informan mengungkapkan alasan rendahnya 
partisipasi pria dalam penggunaan vasektomi adalah bertentangan dengan agama (7 informan), bisa mengakibatkan impotensi (5 informan) dan karena ketidaktahuan tentang vasektomi (3 informan). Sementara motivasi pria menggunakan vasektomi adalah untuk menjaga kesehatan isteri (9 informan), tidak ingin punya anak lagi (7 informan), dan karena isteri tidak cocok ber-KB (4 informan).

"katonyo dak sesuai agama, terus biso membuat impoten"'(informan 3)

"dak tahu kalo ado KB itu..." (informan 4)

"ikut KB vasektomi.. mulonyo ibu be-KB tapi galak pingsan" (informan 1)

"dulu isteri pasang KB selalu gagal pasti kebobolan terus, ee.. sudah lahir anak keenam, sayo putuskan nak di vasektomi be.. karena lah dak pengen punyo anak lagi" (informan 2)

"biasonyo kasian dengan isteri karno pas hamil dan melahirkan suka ado penyakit berat, tensi naik. badan bengkak.. kasian" (informan 5)

\section{Pengetahuan}

Meskipun sebagian besar informan mengetahui tentang prosedur vasektomi sebagai tindakan operasi untuk mengikat/memotong saluran mani suami guna mencegah pembuahan sel telur istri sehingga tidak hamil (9 informan), secara umum pengetahuan informan tentang vasektomi masih rendah terutama terkait aspek yang dipertimbangkan dalam memilih vasektomi; kelebihan dan keterbatasan vasektomi; serta kondisi pria tidak bisa dilakukan vasektomi.

"operasi untuk motong saluran mani supayo dak do buahi sel betino kito..." (informan 1) "operasi dari dokter... kito dioperasi untuk diikat saluran pembuahan ... sel jantan kito tu dak dapat lagi buahi sel betino..." (informan 3)

7 dari 10 informan mengungkapkan aspek yang dipertimbangkan pria memilih vasektomi adalah jika sudah cukup anak, sisanya adalah ada persetujuan isteri (3 informan), dan aspek keamanan (2 informan).

"pertimbangannyo, menurut sayo kalo lah banyak anak... (informan 1)

"kalo anak sudah cukup" (informan 6)

"jumlah anak sudah dirasakan cukup, isteri setuju.. lalu dipastikan prosedurnya aman bagi tubuh..." (informan 7)

Wawancara informan mengungkapkan kelebihan metode vasektomi adalah lebih efektif mencegah kehamilan (6 informan), meningkatkan kesehatan ibu (3 informan), aman karena tidak memiliki efek samping (3 informan), tidak mengganggu kenikmatan dalam berhubungan intim (3 informan), dan gratis (2 informan). Sementara keterbatasan dari vasektomi adalah tidak dapat memiliki anak lagi (8 informan), menyebabkan impoten (3 informan) dan dilarang agama (3 informan).

"kelebihan... mungkin paten lah dak biso lagi beranak..." (informan 3)

" istri makin sehat dan idak bayar" (informan 1)

"kalo pake kondom... dak enak pas campur.. dak ado efek samping... idak bayar..." (informan 4)

"...istri makin sehat, sudah dak sering pingsan lagi... idak ado efek sampingnyo..." (informan 2) "operasi... ado efek sampingnyo" (informan 6)

"pengen punyo anak lagi macam mano? (informan 5)

"biso lemah kito... makonyo agama ada melarang” (informan 8) 
Terkait kondisi pria tidak boleh menggunakan vasektomi, 9 dari 10 informan menyatakan yaitu jika masih ingin punya anak lagi dan sisanya yaitu jika berpenyakit berat ( 3 informan).

"masih mau punyo anak lagi apo idak.. kalo masih.. dak boleh" (informan 2)

"ketiko ado penyakit berat" (informan 3)

\section{Promosi dan Informasi}

6 dari 10 informan menyatakan akses promosi dan informasi tentang metode vasektomi sangat terbatas dan metode $\mathrm{KB}$ yang dikenal hanya kondom. Informasi $\mathrm{KB}$ paling banyak bersumber dari PLKB dan Bidan (4 informan), sedangkan dari televisi, radio, koran termasuk media lain seperti poster atau leaflet jarang diperoleh (9 informan). Penyuluhan KB untuk pria jarang dilakukan (6 informan) dan konseling $\mathrm{KB}$ hanya dilakukan untuk calon akseptor saja (2 informan). Hasil telaah dokumen diketahui bahwa penyuluhan KB dilakukan maksimal dua kali setahun tergantung kegiatan dan anggaran Dinas KB.

"kito ni kan (pria) pake kondom" (informan 2)

"biasonyo taunyo suntik, implant, spiral.. untuk kito (pria)... kondom..." (informan 3)

"informasi KB Pria ko dari petugas KB tapi jarang, dari ibu Bidan jugo (informan 1)

"TV radio idaklah.. kalu koran dak do nyampe siko... poster?.. dak ado" (informan 2)

"katonyo dari bidan, pegawai BKKBN... disitu dikasih penerangan vasektomi. Poster, leaflet, koran dak do nian ..." (informan 4)

"ke ibu-ibu... kan yang banyak be KB dan galak ngumpul tuu ibu-ibu” (informan 6)

"dak pernah penyuluhan KB pria... konseling?? Sayo dak tau...” (informan 8)

"Penyuluhan biasanya dua kali setahun. yang hadir tuu ibu-ibu..." (informan 5) "sekitar satu duo kali lah setahun penyuluhan, tergatung ...anggaran" (informan 6)

"dulu waktu nak operasi, berapo kali konsultasi.. sudah operasi dak lagi" (informan 2)

\section{Akses Pelayanan}

Gambaran akses pelayanan KB metode vasektomi meliputi akses ke tempat pelayanan, biaya pelayanan, dan waktu pelayanan. Hasil wawancara menunjukkan seluruh informan menyatakan akses pelayanan vasektomi masih sulit dijangkau karena harus dilakukan di rumah sakit di Kota Jambi. Waktu pelayanan vasektomi tidak ada jadwal khusus, namun tergantung keberadaan calon akseptor dan harus disampaikan terlebih dahulu ke petugas KB (PLKB) setempat (7 informan). Terkait biaya, 5 dari 10 informan menyatakan vasektomi tidak ada dikenakan biaya karena dijamin pemerintah (BKKBN), meski diakui tetap ada biaya yang harus dikeluarkan yaitu biaya transport dan akomodasi keluarga yang ikut ke rumah sakit (3 informan).

\footnotetext{
"sayo waktu mau operasi menghubungi petugas $K B$ trus petugas $K B$ membawa sayo ke RS DKT Jambi” (informan 1)

"waktu pelayanan KB pria dak ado... yang nak KB daftar dulu ke PLKB" (informan 2)

"daftar ke PLKB.. kagek tu PLKB lah bagi tau bilo waktu operasi..." (informan 4)

"galonyo ditanggung kantor KB" (informan 1)

"adolah biaya dikit untuk ongkos mobil dan makan keluargo di rumah sakit (informan 2)

"kita tidak ada tempat pelayanan KB Pria di kabupaten karno belum kerjasama... proses operasi kerjasama BKKBN Perwakilan Jambi dengan RS DKT Jambi... tidak ada waktu pelayanan khusus.., ee kita hanya bantu mendaftarkan dan ee.. bantu pas pelaksanaan operasi... Untuk biaya operasi vasektomi memang tidak dibebankan pada akseptor,
} 
sudah dianggarkan APBD/APBN jadi gratis" (informan 7)

\section{Sosial Budaya}

Aspek sosial budaya meliputi nilai-nilai sosial budaya dan agama yang mempengaruhi penggunaan vasektomi. Seluruh informan menyatakan budaya masyarakat di Kecamatan Maro Sebo tidak mempermasalahkan jenis kelamin anak, baik laki-laki ataupun perempuan sama saja. Sedangkan terkait pandangan "banyak anak banyak rezeki" sudah tidak berlaku lagi di masyarakat, dan jumlah anak yang ideal adalah 2 hingga 3 orang.

"Pemahaman masyarakat sini tentang jenis kelamin anaknyo, laki-laki perempuan sama" (informan 5)

"...orang-orang di siko... dak terlalu permasalahkan aa.. apo anak jantan, apo betino.. dianggap samo be lah.. yang penting punyo anak, tu lah..." (informan 7)

"banyak anak banyak rezeki tu istilah lamo... dak pake lagi di zaman kini ko" (informan 1) "banyak anak bearti besak pulo beban keluarga belum lagi kalu sakit, nak sekolah, nyari duit susah, duo-tigo anak jadilah" (informan 3)

Dari hasil wawancara, 5 dari 10 informan menyatakan masyarakat masih menganggap $\mathrm{KB}$ adalah urusan perempuan karena ia yang mengalami kehamilan dan melahirkan. Vasektomi juga dianggap dapat menyebabkan hilang kejantanan pria (impoten) sehingga dinilai bisa mengganggu keharmonisan keluarga.

"KB ko sebenarnyo urusan kaum betino lah yoo.. kito ni mendukung be lah" (informan 1) "eloknyo ibu-ibu be lah yang KB ko... kan dio yang hamil, melahir...” (informan 3)

"kebanyakan masyarakat berpikir, KB tu urusan perempuan" (informan 7).
"Operasi tu kato orang biso buat kito dak do jantan lagi hee.." (informan 1)

"orang banyak bilang kalo operasi pria efeknyo dak bagus. biso impoten.. kan bahayo" (informan 2)

"ada bilang bisa bikin impoten.. kita sudah berupaya memberi penjelasan, mungkin itu hanya dampak psikis saja..." (informan 7)

Dari sisi agama, mayoritas informan masih menganggap vasektomi bertentangan dengan ajaran agama karena dianggap merusak tubuh yang telah sempurna. Menurut informan, apa yang telah diciptakan Tuhan, tidak sepatutnya untuk ditiadakan atau dirubah, karena berarti tidak mensyukuri nikmat Tuhan. Metode yang disarankan paling tepat mengatur kelahiran anak guna meningkatkan kesejahteraan keluarga adalah kondom atau senggama terputus.

"kato kyai haram hukumnyo... barang elokelok dirusak..." (informan 3)

"ulama ado yang bilang haram selagi biso make caro lain... takut bawo mudarat" (informan 4)

"di masyarakat memang masih ada pemahaman KB vasektomi itu dilarang agama.. ee seperti berdosa karena telah merusak organ tubuh yang normal" (informan 9)

"itu samo be menghilangkan rahmat Allah... kan bapaknyo biso pake kondom atau keluar di luar be (senggama terputus)" (informan 10)

\section{PEMBAHASAN \\ Partisipasi Pria}

Hasil penelitian menunjukkan partisipasi pria menggunakan kontrasepsi vasektomi di Kecamatan Maro Sebo masih sangat rendah yang disebabkan karena selain tingkat pemahaman masyarakat tentang vasektomi yang masih kurang, juga masih adanya penilaian bahwa vasektomi bertentangan dengan ajaran agama. 
Sementara alasan utama seorang pria menggunakan vasektomi lebih kepada untuk menjaga kesehatan isteri yang mengalami gangguan/masalah kesehatan apabila menggunakan kontrasepsi atau saat hamil dan melahirkan. Kondisi ini sejalan dengan penelitian sebelumnya yang membuktikan bahwa rendahnya partisipasi pria ber-KB berhubungan dengan faktor sosial budaya masyarakat dan pengetahuan pria dalam berKB yang masih rendah 11,12,13. Faktor penyebab rendahnya partisipasi pria dalam ber-KB mencakup diantaranya adalah pengetahuan dan sosial budaya masyarakat dan keluarga ${ }^{14}$. Partisipasi pria ber-KB sangatlah penting terutama saat isteri tidak dapat menggunakan kontrasepsi. Untuk itu, perlu upaya sosialisasi dan diseminasi informasi yang lebih intensif tentang program KB Pria, meningkatkan ruang konsultasi dan pelayanan konseling KB bagi pria.

\section{Pengetahuan}

Pengetahuan salah satu unsur penting dari partisipasi. Bersumber dari pengetahuan, akan tumbuh kesadaran dan akhirnya terwujud perubahan sikap dan perilaku. Hasil penelitian ini menemukan rendahnya pengetahuan informan tentang vasektomi sebagai salah satu metode kontrasepsi terutama tentang aspek apa yang dipertimbangkan dalam memilih metode vasektomi; kelebihan dan keterbatasan vasektomi; dan kondisi pria tidak dapat dilakukan vasektomi. Rendahnya pengetahuan tentang vasektomi ini berkemungkinan besar berpengaruh terhadap rendahnya partisipasi pria memilih vasektomi sebagai alternatif metode KB. Penelitian Sureni, dkk (1999) mengungkapkan hanya $6,2 \%$ dari seluruh akseptor pria yang mengetahui metode kontrasepsi secara lengkap ${ }^{15}$. Studi BKKBN (1999) memperlihatkan sebagian besar pria di Jakarta dan Yogyakarta memiliki pengetahuan terbatas tentang tujuan $\mathrm{KB}$ sehingga kurang menyadari pentingnya $\mathrm{KB}^{16}$.

Pengetahuan berpengaruh pada partisipasi pria ber-KB dimana menyumbang peran penentu dalam pengambilan keputusan memilih kontrasepsi. Makin tinggi pengetahuan pria tentang KB dan kontrasepsi, maka perannya dalam pengambilan keputusan akan semakin baik ${ }^{17,18}$. Faktor rendahnya pengetahuan tentang vasektomi menjadi penyebab masyarakat tidak menjadikannya sebagai kontrasepsi pilihan ${ }^{19}$. Oleh karena itu, perlu upaya sosialisasi dan diseminasi informasi yang intensif untuk meningkatkan pengetahuan pria guna meningkatkan partisipasinya dalam program KB khususnya metode vasektomi.

\section{Promosi dan Informasi}

Hasil penelitian ini menunjukkan akses informasi tentang kontrasepsi vasektomi pada pria di Kecamatan Maro Sebo masih sangat terbatas. Informasi KB Pria umumnya hanya bersumber dari PLKB dan Bidan. Penyuluhan KB pun jarang dilakukan yaitu maksimal hanya dua kali setahun dan itupun biasanya fokus pada KB wanita. Sementara pelayanan konseling hanya dilakukan jika ada calon akseptor vasektomi. Informasi yang terbatas ini berkemungkinan memiliki pengaruh terhadap rendahnya partisipasi pria dalam menggunakan vasektomi di Kecamatan Maro Sebo. Sejalan studi BKKBN (2001) bahwa akses informasi $\mathrm{KB}$ yang diberikan petugas masih terbatas serta bias gender yaitu dari petugas KB $(67,2 \%)$, bidan $(32,8 \%)$, dokter (13\%), dan tokoh agama $(9,7 \%)^{11}$. Rendahnya partisipasi KB pria karena terbatasnya informasi tentang peranan pria dalam program KB termasuk di sarana pelayanan kesehatan ${ }^{20}$. 
Akses informasi sebagai bagian kualitas pelayanan $\mathrm{KB}$ sangat signifikan mempengaruhi partisipasi KB pria ${ }^{12}$. Informasi yang lengkap akan sangat diperlukan guna memutuskan metode kontrasepsi yang akan dipakai ${ }^{21,22}$. Informasi yang perlu diberikan pelayanan $\mathrm{KB}$, antara lain: jenis kontrasepsi, syarat-syarat akseptor, manfaat dan efek samping, syarat dan prosedur penggunaan; inform choice untuk membantu menentukan pilihan; dan waktu kontrol ulang. Akses informasi yang akurat merupakan bagian dari kualitas layanan KB untuk meningkatkan pengetahuan, penerimaan, penggunaan, kepuasan, dan kelangsungan dalam pemakaian kontrasepsi ${ }^{23}$. Perbaikan informasi layanan kontrasepsi untuk meningkatkan proporsi pemakaian kontrasepsi yang memberi pilihan dalam pengaturan kelahiran dan ukuran keluarga $^{24}$. Oleh karena itu, perlu upayaupaya peningkatan akses informasi KB pada pria melalui sosialisasi, penyuluhan dan konseling secara intensif untuk membantu pria membuat keputusan menggunakan vasektomi.

\section{Akses Pelayanan}

Terbatasnya akses pelayanan merupakan aspek yang berpengaruh terhadap rendahnya partisipasi pria dalam ber-KB ${ }^{9}$. Penelitian ini menunjukkan akses pria di Kecamatan Maro Sebo untuk mendapatkan pelayanan vasektomi masih terbatas, antara lain sulitnya menjangkau tempat layanan karena jauh dari tempat tinggal dan waktu pelayanan yang tidak pasti dan tidak terjadwal, meski biaya pelayanan vasektomi telah mendapat disubdisi dari pemerintah. Ketersediaan sarana pelayanan berdampak positif pada penggunaan kontrasepsi dimana kemudahan akses pelayanan akan meningkatkan proporsi pemakaian kontrasepsi ${ }^{24}$. Studi Ekarini (2008) membuktikan akses pelayanan KB berhubungan dengan partisipasi pria ber-KB terbukti dari pria yang tidak menggunakan kontrasepsi mayoritas kesulitan mengakses pelayanan $\mathrm{KB}^{12}$.

\section{Sosial Budaya}

Hasil studi ini menunjukkan adanya nilai sosial budaya dan agama di masyarakat yang mendukung dan yang tidak mendukung program KB. Banyak faktor yang menjadi penyebab rendahnya partisipasi pria ber-KB dari aspek sosial budaya, dan umumnya kurang menguntungkan ${ }^{14}$. Berbagai anggapan masyarakat di Kecamatan Maro Sebo yang tidak tepat dan kurang mendukung tentang KB menjadi hambatan dalam meningkatkan partisipasi pria menggunakan vasektomi, antara lain: 1) $\mathrm{KB}$ adalah urusan isteri; 2) vasektomi menyebabkan impotensi; 3) vasektomi bertentangan dengan ajaran agama Islam.

Pandangan bahwa KB hanya urusan isteri, tidak terlepas dari kerja operasional program KB sendiri yang cenderung dan lebih fokus mengarah ke wanita saja karena mengalami langsung proses kehamilan dan persalinan $^{25}$. Ini tergambar dari kegiatan sosialisasi atau penyuluhan KB di Kecamatan Maro Sebo yang seringkali membahas tentang KB wanita saja. Selanjutnya adanya salah persepsi dan pandangan negatif dari masyarakat bahwa vasektomi identik dengan pengebirian terkait penurunan seksualitas pria menimbulkan kekhawatiran dan keengganan menggunakan vasektomi ${ }^{12,13,14}$. Selain itu, salah satu alasan pria tidak memilih vasektomi adalah karena tidak diperbolehkan atau tidak sesuai ajaran agama khusunya agama Islam dimana sebagian besar tokoh masyarakat dan tokoh agama di Kecamatan Maro Sebo menganggap hukum vasektomi adalah haram karena merusak atau merubah apa yang telah sempurna diciptakan Tuhan kecuali dalam 
kondisi terdesak. Vasektomi juga dianggap memberi dampak tidak baik karena mendorong suami untuk berselingkuh.

Agama Islam pada dasarnya tidak melarang $\mathrm{KB}$ asalkan untuk menjaga kesehatan, karena melahirkan terlalu sering, terlalu dekat jaraknya, terlalu muda dan terlalu tua akan membahayakan kesehatan ibu dan anak. Agama Hindu memandang setiap kelahiran harus membawa manfaat, untuk itu kelahiran harus diatur. Agama Budha dan Kristen Protestan tidak melarang umatnya memakai KB demi kesejahteraan, berbeda dengan agama Katolik yang memandang kesejahteraan keluarga diwujudkan dalam pemahaman holistik sesuai kehendak Tuhan (http://www.bkkbn.go.id diakses pada tanggal 12 Februari 2019). Kondisi di atas menjadi hambatan sekaligus tantangan yang harus menjadi perhatian guna meningkatkan partisipasi pria ber-KB khususnya dalam menggunakan vasektomi.

\section{KESIMPULAN}

Partisipasi pria dalam penggunaan kontrasepsi vasektomi di Kecamatan Maro Sebo masih sangat rendah disebabkan kurangnya pengetahuan tentang vasektomi, rendahnya akses masyarakat terhadap promosi dan informasi tentang vasektomi, akses pelayanan kontrasepsi vasektomi yang masih terbatas, dan masih adanya nilai sosial budaya di masyarakat yang kurang mendukung program KB khususnya penggunaan kontrasepsi vasektomi. Perlunya peningkatan pembinaan secara berkesinambungan oleh Instansi terkait yaitu Dinas Pemberdayaan Perempuan dan Keluarga Berencana Kabupaten Muaro Jambi melalui kegiatan sosialisasi, penyuluhan, dan konseling KB secara intensif dan kontinyu dengan sasaran pria (suami) melalui berbagai media yang efektif dan efisien, serta melakukan pendekatan dan koordinasi dengan tokoh masyarakat dan tokoh agama untuk memperoleh dukungan terhadap program KB khususnya penggunaan kontrasepsi vasektomi bagi pria.

\section{REFERENSI}

1. Akinleye, G.A and Alade, F.A. 2008. Relationships among Family Planning, Sexual Fulfillment and Marital Satisfaction of Married People in Lagos State, Nigeria. The Social Sciences, 3: 343-346. URL: http://medwelljournals.com/abstract/? doi=sscience.2008.343.346

2. Survei Demografi dan Kesehatan Indonesia 2017. Badan Kependudukan dan Keluaraga Berencana Nasional. Jakarta. 2018.

3. Saifudin, A.B., 2006b. Buku Panduan Praktis Pelayanan Kontrasepsi. Yayasan Bina Pustaka Sarwono Prawirohardjo. Jakarta.

4. Rizkitama, AA dan Indrawati, F. 2015. Hubungan Pengetahuan, Persepsi, Sosial Budaya dengan Peran Aktif Pria Dalam Vasektomi di Kecamatan Paguyangan Kabupaten Brebes Tahun 2011-2012. Unnes Journal of Public Health (1). http://journal.unnes.ac.id/sju/index.php/ujph.

5. BKKBN, 2016. Laporan Kinerja Program KB. Jambi.

6. Population Reports. 2003. New Survey Findings: The Reproductive Revolution Continues, Series M, Number 17, Spring diakses pada tanggal 25 April 2019 dari: https://www.k4health.org/sites/default/files/ M\%2017.pdf

7. Notoatmodjo, S., 2014, Ilmu Perilaku Kesehatan, Cetakan ke-2, Rineka Cipta. Jakarta.

8. Bertrand, 1994. Kerangka Pikir Konseptual Permintaan KB serta Dampaknya Pada Fertilitas. Peningkatan Akses dan Kualitas Pelayanan KB. BKKBN. Bandung.

9. BKKBN, 2007. Faktor-Faktor yang mempengaruhi Rendahnya Partisipasi Pria dalam KB. URL: http://www.bkkbn.go.id/gemapria/infodetail.php. diakses tanggal 12 April 2019. 
10. Sugiyono. 2015. Metode Penelitian Kombinasi (Mix Methods). Bandung: Alfabeta.

11. BKKBN, 2001. Studi Kualitatif Fokus Group Diskusi Identifikasi Sasaran Khalayak tentang Partisipasi Pria dalam Keluarga Berencana dan Kesehatan Reproduksi di Propinsi Jawa Tengah dan Jawa Timur. Kerjasama Puslitbang KB dan Kesehatan Reproduksi/Pusna danPuslitbang KS dan PP/Pusra, BKKBN. Jakarta.

12. Ekarini, S, 2008. Analisis Faktor-faktor yang Berpengaruh terhadap Partisipasi Pria dalam Keluarga Berencana di Kecamatan Selo Kabupaten Semarang. Tesis. Universitas Diponegoro.

13. Budisantoso, S., 2009. Partisipasi Pria dalam Keluarga Berencana di Kecamatan Jetis Kabupaten Bantul. Tesis. Universitas Diponegoro. Jurnal. Promosi Kesehatan Indonesia 4 (2) : 103-115.

14. Endang, 2002. Buku Sumber Keluarga Berencana, Kesehatan Reproduksi, Gender, dan Pembangunan Kependudukan. BKKBN \& UNFPA. Jakarta.

15. Sureni, dkk., 1999. Studi Gender Peranan Pria dalam Penggunaan Kontrasepsi di propinsi DIY. Kanwil BKKBN DIY \& PSW UMY. Yogyakarta.

16. BKKBN, 1999. Peningkatan Peran Komponen KIE dalam Gerakan KB Nasional: Studi Kualitatif Peran Pria dalam Penggunaan Kontrasepsi di DKI Jakarta dan D.I. Yogyakarta. Kerjasama PUBIO dengan Pusat Penelitian Pengembangan Pelayanan Kesehatan. Balitbang Depkes. Jakarta.

17. Purwoko, 2000. Penerimaan Vasektomi dan Sterilisasi Tuba. Tesis. Fakultas Kedokteran Universitas Diponegoro. Semarang.

18. Dewi, V, 2009. Factors hat Influence Male Participation in Family Planning and Reproductive Health in Indonesia 2009. Thesis, School of Geography, Population and Environmental Management, Flinders University of South Australia, Adelaide.

19. Wijayanti, T., 2004. Studi Kualitatif Alasan Akseptor Laki-Laki tidak Memilih MOP sebagai Kontrasepsi Pilihan di desa Timpik kecamatan Susukan kabupaten Semarang. Program Studi D IV Kebidanan. Stikes Ngudi Waluyo. Ungaran.

20. Asan, A., 2007. Hak Reproduksi Sebagai Etika Global dan Implementasinya dalam Pelayanan KB/KR di NTT Tahun 2007. BKKBN, NTT.

21. Bessinger, R.E., \& Bertrand, J.T., 2001. Monitoring Quality of Care in Family Planning Program: A Comparison of Observations and Client Exit Interviews. International Family Planning Perspective.

22. Katz, K.R., Jhonson, L.M., Janowitz, B., \& Carranza, J.M., 2002. Reason for the Low of IUD Use in El Savador, International Family Planning Perspectives.

23. Bruce, J., 1990. Fundamental Elements of the Quality of Care, A Simple Frams Work Studies in Family Planning.

24. Satyavada, A., and Adamchak, D.J. 2000. Determinants of Current Use of Contraception and Children Ever Born in Nepal. Social Biology. Spring-Summer.; 47 (1-2): 51-60. URL: https://www.ncbi.nlm.nih.gov/pubmed.

25. Sumadi, 2007. Profil Paguyuban KB Pria Prio Utomo Ngudi Raharjo dukuh Brajan Desa Senden Kecamatan Selo Kabupaten Boyolali. Paguyuban KB Prio Utomo "Ngudi Raharjo". Senden. 